\title{
Személyiség, érzelmi intelligencia és élettel való elégedettség
}

\author{
BÁNYAI-NAGY HENRIETT* \\ Eötvös Loránd Tudományegyetem, Pedagógiai és Pszichológiai Kar, Pszichológiai \\ Intézet, Budapest
}

(Beérkezett: 2017. december 7.; elfogadva: 2018. március 22.)

\begin{abstract}
Elméleti háttér: A korábbi kutatások szignifikáns összefüggést jeleztek az érzelmi intelligencia és a jóllét különböző mutatói között. A kapcsolat erőssége nagymértékben változott annak függvényében, hogy az érzelmi intelligencia mérése milyen módszerrel történt, illetve egyelőre nem tisztázott, hogy az érzelmi intelligencia a Big Five faktorok kontrollálása mellett is a szubjektív jóllét szignifikáns magyarázótényezőjének tekinthetó-e. Cél: Jelen tanulmány a Big Five személyiségfaktorok, a vonás jellegú és képességalapú érzelmi intelligencia és az élettel való elégedettség összefüggéseit vizsgálja. Módszerek: Keresztmetszeti kutatásunkban 421 fő vett részt (166 férfi és 255 nő). Az eljárás során az alábbi kérdőíveket töltötték ki a résztvevők: Érzelmek Mérése Skála (AES-HU), Érzelemszabályozás Szituációs Teszt (STEM), Ekman 60 Arc Teszt, Big Five Kérdőív (BFI), Élettel való Elégedettség Skála (SWLS). Eredmények: Eredményeink szerint négy Big Five dimenzió (extaverzió, barátságosság, lelkiismeretesség, nyitottság) pozitív, a neuroticizmus pedig negatív korrelációt mutat mind az élettel való elégedettséggel $(r=0,20-0,33 ; p<0,01)$, mind a vonás érzelmi intelligenciával $(r=0,21-0,55 ; p<0,01)$. A hierarchikus lineáris regresszió elemzés eredményei szerint az extraverzió, a neuroticizmus és a vonás érzelmi intelligencia is szignifikáns önálló magyarázóerővel bír az élettel való elégedettség vonatkozásában. A vonás érzelmi intelligencia azután is szignifikáns hányadot magyaráz az SWLS pontszámok varianciájából miután kontrolláljuk a Big Five faktorokat (korrigált $\mathrm{R}^{2}$ $=0,231 ; F(7,413)=21,016 ; p<0,001)$. Ezzel ellentétes módon a vizsgált képességalapú érzelmi intelligencia-mutatók függetlennek bizonyultak mind a személyiségtől, mind pedig az élettel való elégedettség szintjétől. Következtetések: Az eredményeink egybecsengnek azokkal a korábbi kutatásokkal, amelyek igazolták, hogy a Big Five faktorok fontos szerepet játszanak az élettel való elégedettségben, illetve demonstrálták, hogy a vonás jellegú érzelmi intelligencia kapcsolatban áll a szubjektív jólléttel.
\end{abstract}

Kulcsszavak: szubjektív jóllét, élettel való elégedettség, személyiség, Big Five faktorok, érzelmi intelligencia

\footnotetext{
* Levelezési cím: Dr. Bányai-Nagy Henriett, Eötvös Loránd Tudományegyetem, Pedagógiai és Pszichológiai Kar, Pszichológiai Intézet, 1064 Budapest, Izabella utca 46. E-mail: nagy.henriett@ ppk.elte.hu
} 


\section{Bevezetés}

Jelen tanulmány az érzelmi intelligencia szubjektív jóllétben betöltött szerepének tisztázásához kíván hozzájárulni. A jóllét tanulmányozásával összefüggésben két fő megközelítés különböztethető meg a szakirodalomban: a hedonikus és az eudaimonikus perspektíva (Ryan \& Deci, 2001). A hedonikus megközelítés elsősorban arra fókuszál, hogy mi teheti kellemessé az életet, mi járulhat hozzá a szenvedés elkerüléséhez és az örömök maximalizálásához. Az eudaimonikus perspektíva pedig a jóllétet az önmegvalósítás és növekedés terminusaiban írja le. E szerint az önismeret (erősségek, gyengeségek, értékek, célok ismerete) szükséges ahhoz, hogy elérjük a boldogság állapotát, amely Arisztotelész szerint a humán létezés végsó célja. A pozitív pszichológia jelenkori megközelítésében a hedonikus jóllét hagyománya elsősorban a szubjektív jóllét koncepciójához (Diener, 1984), az eudaimonikus jóllét pedig a pszichológiai jóllét modelljéhez kapcsolódik. A szubjektív jóllét modell azt feltételezi, hogy a jóllét lényegi eleme a szubjektivitás, és abból indul ki, hogy mivel minden személy más, különböző értékeket képviselnek, különböző dolgok meghatározóak és fontosak számukra, ezért mindig az adott személy szemszögéból lehet csak megközelíteni a boldogságot. A modell második fontos állítása szerint a jóllét nem egy homogén, egységes dolog, ehelyett fontos a szubjektív jóllét különböző komponenseit elkülöníteni. Diener (1984) azt feltételezte, hogy a pozitív érzelmi állapotok gyakori jelenléte, és a negatív érzelmek relatív hiánya, valamint egy élettel való általános elégedettségérzet a szubjektív jóllét alapvető komponensei. Jelen kutatás a jóllét mutatói közül kizárólagosan az élettel való elégedettségre fókuszál, amely a személy saját életére vonatkozó globális értékelését takarja (Diener, 2000). Legújabban Proctor, Tweed és Morris (2014) rámutattak arra, hogy az élettel való elégedettség egy magasabb rendú jóllét-kategóriának is tekinthető, amely egyaránt ötvözi a jóllét hedonikus és eudaimonikus aspektusait, vagyis ha bármelyik területen jól múködünk, az tükröződhet az élettel való elégedettségünkben.

Salovey és Mayer az 1990-ben megjelent, az érzelmi intelligenciáról szóló legelső tanulmányban a személyes növekedésben hangsúlyozták az érzelmi intelligencia jelentőségét. Meghatározásuk szerint az érzelmi intelligencia azokat az érzelmek kifejezéséhez, észleléséhez, felhasználásához és kezeléséhez kötődő képességeket integrálja, amelyek a személy fejlődését biztosítják. A képességalapú érzelmi intelligencia modell leírói azt állítják, hogy a fenti képességek egy, az IQ-tól világosan megkülönböztethető, önálló intelligenciaformát alkotnak. A későbbi meghatározások (az érzelmi intelligencia úgynevezett kevert modelljei) az érzelmi intelligenciát mentális 
képességek, társas kompetenciák, bizonyos személyiségjellemzók és motivációs faktorok együtteseként írták le. E modellek közül a legismertebb Bar-On (1997) elképzelése, amely szerint: „az érzelmi intelligencia azon érzelmi, személyes és társas kompetenciák, valamint készségek együttese, amelyek hozzájárulnak ahhoz, hogy a személy eredményesen küzdjön meg környezete követelményeivel" (Bar-On, 1997, 17. o.).

Az érzelmi intelligencia mérésével kapcsolatban jelenleg két eltérő megközelítéssel is találkozunk a szakirodalomban: egyrészt teljesítményteszteket, másrészt önbeszámolón alapuló kérdőíveket dolgoztak ki a konstruktum mérésére. Petrides és Furnham (2001) a kétféle módszertan alkalmazásával operacionalizált érzelmi intelligencia világos megkülönböztetése céljából a vonás jellegú érzelmi intelligencia, illetve a képességalapú érzelmi intelligencia címkék bevezetését javasolta. Az önjellemző kérdőívek alkalmazásával mért vonás érzelmi intelligencia az érzelmek önészlelésének konstellációja, egyfajta érzelmi énhatékonyság-érzetet jelent, viselkedéses diszpozíciókra és önjellemzésekre vonatkozik a személy azon kapacitásaival kapcsolatban, hogy felismerje, feldolgozza és hasznosítsa az érzelmi információkat. A teljesítménytesztekkel mért képesség érzelmi intelligencia edig a személy aktuális képességeire vonatkozik, hogy felismerje, feldolgozza és felhasználja az érzelmi információkat az adaptívabb múködés érdekében.

Néhány kutatásban jelentős átfedést találtak a vonás érzelmi intelligencia és a Big Five között (pl. Webb és mtsai, 2013). Andrei, Siegling, Aloe, Baldaro és Petrides (2016) recens metaelemzése szerint a vonás érzelmi intelligencia nem egyforma mértékben korrelál a Big Five faktorokkal: a legerősebb összefüggést a neuroticizmussal, a barátságossággal és a lelkiismeretességgel mutatja, az extraverzióval és nyitottsággal való együttjárása pedig kevésbé jelentős. A vonás, illetve képesség érzelmi intelligencia és a testi-lelki egészségi állapot összefüggésére vonatkozó metaelemzések (Martins, Ramalho, \& Morin, 2010; Schutte, Malouff, Thorsteinson, Bhuller, \& Rooke, 2007) azt mutatják, hogy az érzelmi intelligencia előre jelzi mind a fizikai, mind a mentális egészségi állapot szintjét. Az ide vonatkozó kutatások eredményei általánosságban azt jelzik, hogy a vonás érzelmi intelligencia szorosabban kapcsolódik a mentális, mint a fizikai egészségi állapothoz. Martins és munkatársai (2010) szerint a nem moderálja a vonás érzelmi intelligencia és egészség kapcsolatát: a megfigyelt hatás erősebb a nők, mint a férfiak esetében. A képesség érzelmi intelligenciára vonatkozólag a kevés rendelkezésre álló kutatás miatt egyelőre nem rajzolódtak ki a vonás érzelmi intelligenciához hasonló módon markáns összefüggések. 


\subsection{A jelen kutatás célkitúzései}

Számos korábbi kutatás igazolta a vonás érzelmi intelligencia és a különböző boldogságmutatók közötti összefüggéseket (Chamorro-Premuzic, Bennett, \& Furnham, 2007; Extramera \& Fernandez-Berrocal, 2005; Kong, Zhao, \& You, 2012; Palmer, Donaldson, \& Stough, 2002; Petrides \& Furnham, 2003; Platsidou, 2013; Urquino, Extremera, \& Villa, 2015), ugyanakkor keveset tudunk a képesség érzelmi intelligencia szubjektív jóllétre gyakorolt hatásáról (Ruiz-Aranda, Extremera, \& Pineda-Galán, 2014). A legtöbb tanulmány arra fókuszált, hogy a globális, vonás jellegú érzelmi intelligencia miképpen határozza meg a boldogság szintjét (pl. Furnham \& Petrides, 2003; Kong és mtsai, 2012), és a szerző tudomása szerint eddig csupán néhány kutatás vizsgálta a specifikus érzelmi intelligencia komponensek szerepét a szubjektív jóllét magyarázatában (Extramera \& FernandezBerrocal, 2005; Palmer és mtsai, 2002; Platsidou, 2013). Egyes kutatások (Extramera \& Fernandez-Berrocal, 2005; Palmer és mtsai, 2002) eredményei rámutattak arra, hogy az érzelmek pontos felismerésének és megkülönböztetésének kapacitása többet megmagyaráz az élettel való elégedettség varianciájából, mint a többi érzelmi intelligencia összetevő. Platsidou (2013) vizsgálatának eredménye pedig azt sugallja, hogy azok a fiatalok, akiknél fejlett az érzelmek értékelésének képessége, magasabb szintú életerőt és személyes hatékonyságérzetet tapasztalnak meg, mint azok a fiatalok, akiknél ez az érzelmi intelligencia összetevő fejletlenebb. Azok a fiatalok pedig, akik optimisták és hatékonyak az érzelmeik szabályozásában, illetve akik fejlett szociális képességekkel rendelkeznek, magasabb szinten tapasztalják a boldogság legtöbb komponensét, mint a kevésbé optimista és az érzelmek szabályozásában kevésbé jártas társaik. Az érzelmi intelligencia és a jóllét összefüggésére irányuló korábbi vizsgálatok nagyrészt nem vették figyelembe a Big Five faktorok esetleges magyarázó szerepét. Elsóként Furnham és Petrides (2003) számolt be arról, hogy a szubjektív boldogságérzet varianciájának több mint $50 \%$-a magyarázható a vonás érzelmi intelligenciával. Ugyanez a kutatás rámutatott arra is, hogy a Big Five vonások nem magyaráznak szignifikáns hányadot a boldogság varianciájából a vonás érzelmi intelligencia kiparciálása után. A későbbi tanulmányok, amelyek a Big Five faktorok kontrollálása mellett vizsgálták az érzelmi intelligencia és jóllét kapcsolatát vagy nem igazolták ezt az összefüggést (Burns, Bastian \& Nettelbeck, 2007; Day, 2004; Rode, Arthaud-Day, Monney, Near, \& Baldwin, 2008), vagy mérsékeltnek találták a vonás érzelmi intelligencia inkrementális validitását (Austin, Saklofske, \& Egan, 2005; Gallagher \& Vella-Brodrick, 2008; Petrides, Pérez-González, \& Furnham, 2007; Saklofske, Austin, Galloway, \& Davidson, 2007). 
Jelen tanulmány az élettel való elégedettség vonatkozásában vizsgálja az érzelmi intelligencia szerepét, és a vonás érzelmi intelligencia mutatói mellett a képesség érzelmi intelligencia komponenseit is figyelembe veszi. Azt teszteljük, hogy a különbözó érzelmi intelligencia összetevők megkülönböztethetó módon kapcsolódnak-e az élettel való elégedettség szintjéhez, figyelembe véve a vonás érzelmi intelligenciával egyébként jelentős átfedést mutató fóbb személyiségfaktorokat is, amelyek a szubjektív jóllét szintjének ismert meghatározói (Diener \& Ryan, 2009). Úgy véljük, hogy a kérdés vizsgálata elméleti és gyakorlati szempontok alapján is lényeges lehet. Az ilyen típusú vizsgálatok segíthetnek tisztázni, hogy mely érzelmi intelligencia összetevők azok, amelyekre kiemelten érdemes fókuszálni azon prevenciós és intervenciós programok tervezése kapcsán, amelyek a jóllét növelését túzik ki célul. Másrészt, az érzelmi intelligencia konstruktum validitásának tisztázása szempontjából is érdekes kérdés lehet annak igazolása, hogy az érzelmi intelligencia egyedülálló módon (vagyis a személyiségtól függetlenül) is képes-e előre jelezni valamilyen adaptív funkciót. A korábbi, fent ismertetett kutatási eredmények alapján azt feltételezzük, hogy az érzelmi intelligencia és az élettel való elégedettség között pozitív irányú kapcsolat lesz, valamint, hogy ez a kapcsolat szignifikáns marad még azután is, hogy a Big Five faktorokra kontrolláljuk az összefüggéseket.

\section{Módszer}

\subsection{Résztvevők}

A kutatásban 18 évnél idősebb, magyar felnőttek vettek részt, összesen 432 fő. Összesen 11 fő adatát távolítottuk el a hiányos tesztkitöltés miatt, így az elemzések során használt minta elemszáma 421 fő (166 férfi és 255 nő). A vizsgálat résztvevői a személyiségpszichológiai múhelymunkán dolgozó BA pszichológushallgatók ismeretségi köréből kerültek ki, és önként jelentkeztek a kutatásban való részvételre. A mintába történó beválasztás egyedüli kritériuma a 18 éven felüli életkor volt. A legfiatalabb részvevő 18, a legidősebb 68 éves volt, az átlagéletkor 23,81 év (SD = 6,81 év). A minta 43,9\%-a $(n=185)$ felsőfokú végzettségú, 53,9\%-nak $(n=227)$ középiskolai végzettsége van, és összesen 9 fó rendelkezik általános iskolai végzettséggel. Családi állapotát tekintve a válaszadók egyik fele $(50,4 \% ; n=212)$ egyedülálló, a másik fele $(49,6 \% ; n=209)$ pedig kapcsolatban él. Az adatgyújtés kényelmi mintavétellel, hólabda módszer alkalmazásával, e-mailes megkeresés útján történt. A kutatásban való részvétel önkéntes és anonim volt. 


\subsection{Eljárás}

A kutatás online felületen történt, a vizsgált személyek az online felület kezdőlapján egy írásos tájékoztatót olvastak a kutatásról, majd a résztvételi szándékukat a „hozzájárulok” gomb megnyomásával jelezték. Ezt követően jelent meg a beleegyező nyilatkozat szövege. Amennyiben a résztvevó egyetértett az ebben foglalt feltételekkel, ezt az „elfogadom" gomb megnyomásával jelezte. A résztvevők az általuk szabadon választott időpontban és helyszínen töltötték ki a kérdőíveket. A kutatást az ELTE PPK Kutatásetikai Bizottsága jóváhagyta (az engedély száma: 2014/142).

\subsection{Mérőeszközök}

Szociodemográfiai adatok: rákérdeztünk a válaszadók nemére, életkorára, iskolai végzettségére és családi állapotára.

A vonás érzelmi intelligenciát az Érzelmek Mérése Skála (Assessing Emotions Scale, AES) alkalmazásával mértük, amely a Salovey és Mayer által 1990-ben leírt érzelmi intelligencia modellre épülő önbeszámolós kérdőív. A válaszadóknak egy ötfokozatú, Likert-típusú skálán kell megítélni, hogy mennyire igazak rájuk nézve a felsorolt állítások. A válaszlehetóségek végpontjai a következők: egyáltalán nem jellemző (1) és teljes mértékben jellemző (5). A kérdőív egyenes és fordított irányú tételeket egyaránt tartalmaz. Az eredeti 33 tételból álló kérdőívet Schutte és munkatársai 1998-ban dolgozták ki. A skálát a publikálás óta számos tanulmányban használták. Ezek többsége támogatta a skála megbízhatóságát és érvényességét (Chiarrochi, Chan, \& Bajgar, 2001; Kun, Balázs, Kapitány, Urbán, \& Demetrovics, 2010; Kun és mtsai, 2011; Saklofske, Austin, \& Minski, 2003; Schutte és mtsai, 2001), illetve a megfogalmazódó kritikai észrevételek alapján a skála számos módosított verziója is publikálásra került. Jelen kutatásban a Gignac, Palmer, Manocha és Stough (2005) elemzésére épülő 28 tételes változat került alkalmazásra (AES-HU; magyar adaptáció: Nagy, 2012), amely a vonás érzelmi intelligencia összesített pontszáma mellett, az alábbi hat alskálával bír: (I) Az érzelmek értékelése önmagunknál, (II) Az érzelmek értékelése másoknál, (III) Az érzelmek kifejezése, (IV) Az érzelmek szabályozása önmagunknál, (V) Az érzelmek szabályozása másoknál, (VI) Az érzelmek felhasználása a problémamegoldásban. Minden alskála és az összesített pontszám esetében is a magasabb pontszám magasabb érzelmi intelligenciát jelez. Jelen kutatásban a vonás érzelmi intelligencia összesített skála belső megbízhatósági mutatója (Cronbach- $\alpha=0,89$ ), valamint a hat alskála belső megbízhatósága is kielégító volt (Cronbach- $a=0,64-0,82$ között). 
Az Érzelemszabályozás Szituációs Teszt (The Situational Test of Emotional Management, STEM; MacCann \& Roberts, 2008; magyar adaptáció: Nagy, Magyaródi, \& Séllei, 2015) empirikus alapú tesztszerkesztésre épül. A STEM 44 tételból áll. Minden tétel egy szituációt ír le, és a tesztkitöltó személynek 4 válaszlehetőség közül kell kiválasztani az adott helyzetben leghatékonyabb reakciót. A teszt instrukciója hangsúlyozza, hogy nem arra vagyunk kíváncsiak, hogy a személy mit tenne az adott szituációban, vagy, hogy szerinte melyik reakció volna a legszimpatikusabb válasz, hanem arra kérjük a tesztet kitöltő személyt, hogy azt a választ jelölje meg, amely szerinte a leghatékonyabb reakciót írja le az adott helyzetben, vagyis amely egyszerre kezeli a személy érzelmeit és oldja meg a felmerülő problémát. MacCann és Roberts (2008) szerint a STEM megfeleló belső megbízhatósági mutatóval jellemezhető. Későbbi kutatások szintén támogatták a STEM reliabilitását (Librecht \& Lievens, 2012; Nagy és mtsai, 2015). A STEM validitását tesztelő korábbi tanulmányok (pl. Librecht \& Lievens, 2012; MacCann \& Roberts, 2008; Nagy és mtsai, 2015) igazolták a teszt érvényességét is. A STEM esetében többféle pontozási rendszer is elterjedt. Jelen kutatásban a dichotóm pontozást alkalmaztuk: a szakértók (klinikai pszichológusok és érzelemkutatók) megítélése alapján leggyakrabban választott megoldások 1 pontot értek, az ettól különbözőek pedig 0 pontot. A magasabb összpontszám fejlettebb érzelemszabályozási képességre (a negatív érzelmek mérséklésének és a pozitívak előidézésének képessége) utal. Jelen kutatásban a skála belső megbízhatósága mérsékelt volt (Cronbach- $\alpha=0,55)$, és a kapott reliabilitásmutató nem volt javítható alacsonyabb item-maradék korrelációjú tételek elhagyásával sem.

Az érzelmi arcfelismerés képességét mérő Ekman 60 Arc Teszt az Ekman és Friesen által 1978-ban összeállított, alapérzelmeket kifejező képgyújteményre épülő módszer. Az Ekman 60 Arc Teszttel kapcsolatos hazai kutatási eredményekról Rózsa és munkatársai 2012-ben számoltak be. Ezek az eredmények támogatják a skála belső megbízhatóságát és érvényességét. A teszt 60 arcról készült fényképet tartalmaz, amelyek 10 személyról (6 férfi és 4 nő) készültek. A fényképeken szereplő személyek mindegyike a hat alapérzelem (düh, undor, félelem, öröm, szomorúság, meglepődés) valamelyikét mutatja. A tesztkitöltő személyek feladata kiválasztani, hogy a hat lehetséges érzelem közül melyik írja le legjobban a látott arckifejezést. A magasabb pontszám az érzelmi arcfelismerési képesség fejlettebb szintjére utal. Jelen kutatásban a teszt belső megbízhatósága mérsékelt volt (az Ekman 60 összpontszám esetén: Cronbach- $\alpha=0,64)$.

A Big Five Kérdőív (Big Five Inventory, BFI; John, Donahue, \& Kentle, 1991, magyar adaptáció: Rózsa, 2010) 44 tételból áll, és a személyiség 5 fő dimenziójának megfeleltethető skálákat tartalmaz: extraverzió, barátságosság, 
lelkiismeretesség, neuroticizmus, nyitottság. A válaszadóknak egy ötfokozatú Likert-típusú skála segítségével kell megjelölni, hogy mennyire illik rájuk a 44 állítás. A válaszlehetóségek végpontjai a következők: egyáltalán nem értek egyet (1) és teljes mértékben egyetértek (5). A kérdőív egyenes és fordított irányú tételeket egyaránt tartalmaz. A skálákon elért magasabb pontszám az extraverzió, barátságosság, lelkiismeretesség, érzelmi instabilitás (neuroticizmus) és nyitottság magasabb szintjeit jelzi. John és Srivastava (1999) vizsgálatának eredményei igazolták a skála belső megbízhatóságát. A korábbi hazai kutatások szintén a mérőeszköz jó pszichometriai jellemzőit támasztották alá (Rózsa és mtsai, 2012). Jelen kutatásban a személyiség fő dimenzióit jelző skálák belső megbízhatósági mutatói megfelelőek voltak (Cronbach- $\alpha=0,62-0,83$ között).

Az Élettel való Elégedettség Skála (Satisfaction with Life Scale, SWLS; Diener, Emmons, Larsen, \& Griffin, 1985) a szubjektív jóllét kognitív komponensének mérésére szolgáló 5 tételból álló, önbeszámolón alapuló kérdőív. A tesztkitöltő személyek hétfokozatú Likert-skálák alkalmazásával értékelik az életükkel való elégedettségüket. A válaszlehetőségek végpontjai a következők: egyáltalán nem értek egyet (1) és teljes mértékben egyetértek (7). A méróeszköz az élettel való elégedettségre globális szinten kérdez rá. A magasabb pontszám az élettel való elégedettség magasabb szintjét jelzi. Nemzetközi (pl. Diener és mtsai, 1985) és hazai vizsgálatok (pl. Martos, Sallay, Désfalvi, Szabó, \& Ittzés, 2014; Szondy, 2010) egyaránt alátámasztották a skála jó pszichometriai jellemzőit. Jelen kutatásban a skála belső megbízhatósága kiváló volt (Cronbach- $\alpha=0,84)$.

\subsection{Statisztikai elemzések}

A skálák belső megbízhatóságának becslésére Cronbach-a mutatót számítottunk. A paraméteres statisztikai eljárások normális eloszlás előfeltételének tesztelése céljából a folytonos változók eloszlását három módon vizsgáltuk: a Kolmogorov-Smirnov póba, a QQ-grafikonok vizsgálatával, valamint a változók eloszlásának egyszerú szemrevételezésével (hisztogramok segítségével). A normalitás előfeltétele minden változó esetében teljesült, ezért az elemzések során parametrikus eljárásokat alkalmaztunk. Független mintás $t$-próba segítségével teszteltük, hogy mutatkozik-e különbség a férfiak és a nők között az élettel való elégedettség tekintetében. Az élettel való elégedettség és az érzelmi intelligencia, valamint a személyiség és az életkor összefüggéseit korrelációs elemzésekkel teszteltük. Hierarchikus lineáris regresszió elemzéssel vizsgáltuk, hogy találunk-e szignifikáns kapcsolatot az érzelmi intelligencia és az élettel való elégedettség között a Big Five faktorok kontrollálása után is. Az elemzéseket a SPSS Statistics 20 alkalmazásával végeztük. 


\section{Eredmények}

A független mintás $t$-próba eredménye szerint nem találtunk szignifikáns különbséget a férfiak $(M=4,39$; $S D=1,21)$ és a nők $(M=4,39$; $S D=1,19)$ között az élettel való elégedettség tekintetében $(t(419)=0,06 ; p=0,995)$.

A vizsgálat alapstatisztikáját, valamint az élettel való elégedettség, az érzelmi intelligencia, a személyiség és az életkor együttjárásaira vonatkozó eredményeket az 1. táblázat mutatja be.

Mind az öt Big Five faktor szignifikáns korrelációt mutatott az élettel való elégedettséggel: a neuroticizmus negatív, a többi faktor (extraverzió, barátságosság, lelkiismeretesség, nyitottság) pozitív irányban. Az extraverzió közepes erôsségú, a többi Big Five faktor gyenge együttjárást mutatott az élettel való elégedettséggel.

A vonás érzelmi intelligencia összpontszám pozitív irányú, közepes erősségú, szignifikáns kapcsolatot mutatott az élettel való elégedettséggel. A vonás érzelmi intelligencia komponensei közül az érzelmek szabályozása önmaguknál mutatta a legszorosabb együttjárást az élettel való elégedettséggel $(r=0,43 ; p<0,001)$. Ugyanakkor megfigyelhetó az is, hogy a vonás érzelmi intelligencia mind az öt Big Five faktorral szignifikáns együttjárást mutat. A kapcsolatok erőssége a gyengétől az erősig terjedt. Szoros együttjárás mutatkozott az extraverzió és a vonás érzelmi intelligencia között $(r=0,54 ; p<0,001)$.

Egészen más eredmények születtek a képesség érzelmi intelligencia és élettel való elégedettség kapcsolatának vonatkozásában. Az érzelmek szabályozásának képessége (STEM) nem mutatott szignifikáns együttjárást az élettel való elégedettséggel, és ugyanez figyelhető meg az Ekman 60 Arc Teszttel mért általános érzelem-felismerési képességre vonatkozóan is. A különböző képesség érzelmi intelligencia-mutatók és a személyiségdimenziók között nem találtunk szignifikáns korrelációs együtthatót, két kivétellel: gyenge, pozitív irányú szignifikáns összefüggés mutatkozott az Ekman 60 Arc Teszttel mért általános érzelem felismerési képesség és a barátságosság között $(r=0,12 ; p=0,010)$, illetve a STEM-el mért érzelemszabályozási képesség és a barátságosság között $(r=0,12 ; p=0,012)$.

Eredményeink szerint továbbá szignifikáns, pozitív irányú, gyenge öszszefüggés mutatkozott az életkor és az élettel való elégedettség között ( $r=$ 0,$22 ; p<0,001$ ), az életkor és a vonás érzelmi intelligencia (AES-HU összpontszám; $r=0,14 ; p=0,005$ ) között, valamint az életkor és az érzelem felismerési képesség (Ekman 60 összpontszám; $r=0,14 ; p=0,003$ ) között. 


\begin{tabular}{|c|c|c|c|c|c|c|c|c|c|c|}
\hline 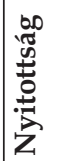 & 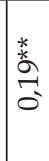 & 贲 & 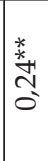 & 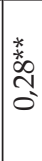 & 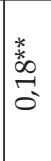 & \begin{tabular}{l} 
* \\
\multirow{2}{*}{0} \\
ñ \\
0
\end{tabular} & $\begin{array}{l}x^{*} \\
\text { N } \\
\text { ñ }\end{array}$ & 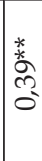 & 恶 & 今 \\
\hline 1 & $*$ & * & $*$ & $\frac{*}{*}$ & & $*$ & & & & \\
\hline
\end{tabular}

\begin{tabular}{|c|c|c|c|c|c|c|c|c|c|c|}
\hline 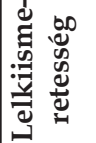 & ָั & \begin{tabular}{l} 
* \\
N \\
\multirow{2}{*}{} \\
ó
\end{tabular} & 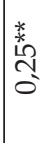 & 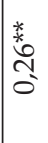 & $\begin{array}{l}{ }^{*} \\
\stackrel{-}{\prime} \\
\end{array}$ & \begin{tabular}{l}
$x$ \\
\multirow{2}{*}{} \\
ma \\
0
\end{tabular} & \begin{tabular}{l}
$\stackrel{*}{*}$ \\
$\stackrel{*}{*}$ \\
\multirow{\sigma}{*}{}
\end{tabular} & 㚆 & 孚 & $\stackrel{8}{8}$ \\
\hline 00 & 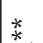 & $*$ & $*$ & $*$ & $*$ & $*$ & $*$ & $\frac{*}{*}$ & & \\
\hline
\end{tabular}

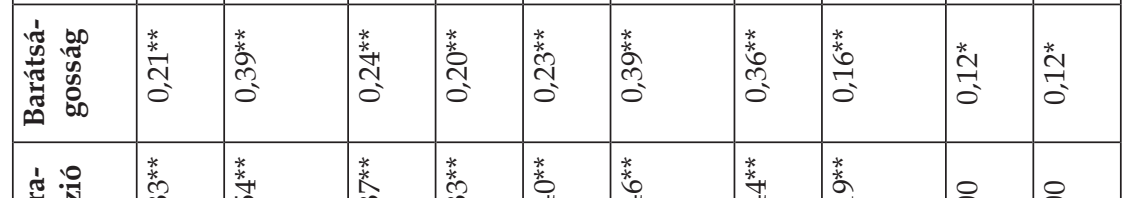

\begin{tabular}{|c|c|c|c|c|c|c|c|c|c|}
\hline 芠 & 嘉 & 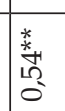 & 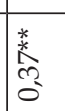 & 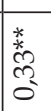 & 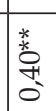 & $\begin{array}{l}\text { 粼 } \\
\text { d }\end{array}$ & 类 & 䊅 & 8 \\
\hline
\end{tabular}

\begin{tabular}{|c|c|c|c|c|c|c|c|c|c|c|}
\hline 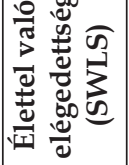 & ' & 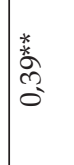 & $\begin{array}{l}\text { 总 } \\
\text { o. } \\
0\end{array}$ & 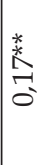 & 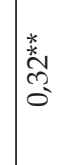 & 嘉 & $\begin{array}{l}\text { * } \\
\text { N } \\
0\end{array}$ & 素 & $\begin{array}{l}t \\
0 \\
i\end{array}$ & $\mid \begin{array}{l}\text { tr } \\
\dot{i}\end{array}$ \\
\hline & 蒡 & 荛 & & & $m$ & * & $\forall$ & * & $\infty$ & 类 \\
\hline
\end{tabular}

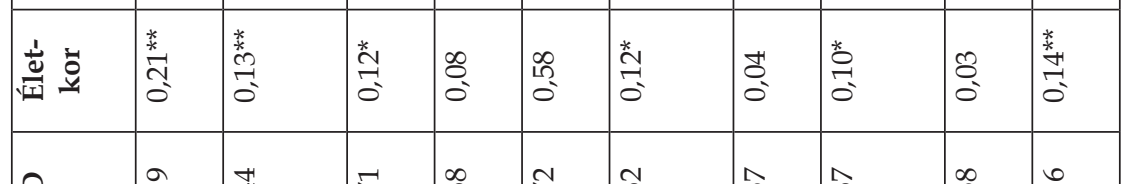

\begin{tabular}{|c|c|c|c|c|c|c|c|c|c|c|c|}
\hline कि & Э્ & 声 & E్ & 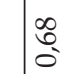 & 第 & $\int_{0}^{\circ}$ & $\mid \begin{array}{ll}10 \\
10 \\
0\end{array}$ & & 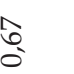 & 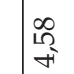 & $\underset{+}{\stackrel{L}{f}}$ \\
\hline & के & 诂 & $\infty$ & $\stackrel{0}{\circ}$ & 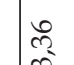 & 7 & $\frac{\alpha}{1}$ & & 员 & 4 & \&. \\
\hline
\end{tabular}

\begin{tabular}{|c|c|c|c|c|c|c|c|c|c|c|}
\hline $\bar{z}$ & $\begin{array}{l}\text { के } \\
\text { +े }\end{array}$ & 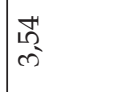 & 焉 & $\begin{array}{l}0 \\
0 \\
c i\end{array}$ & $m_{m}^{\circ}$ & 总 & $\begin{array}{l}\infty \\
c^{\infty}\end{array}$ & 总 & $\begin{array}{l}\text { 量 } \\
\text { and }\end{array}$ & 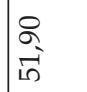 \\
\hline 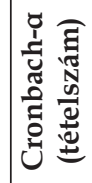 & 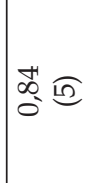 & 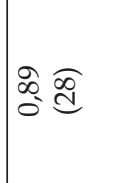 & 菅 $\widehat{d}$ & $\begin{array}{l}\alpha_{0} \\
\infty \\
0 \\
0\end{array}$ & : & क्ठ் & $\begin{array}{l}\text { Lot } \\
0 \\
0\end{array}$ & 总开 & 虽乎 & 菅遂 \\
\hline 总 & 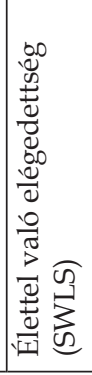 & 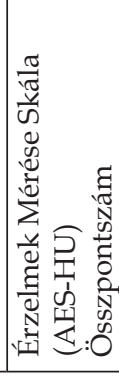 & 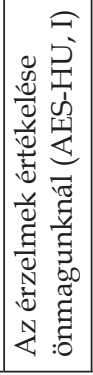 & 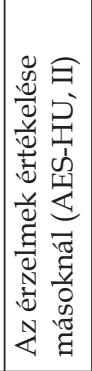 & 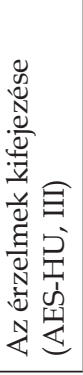 & 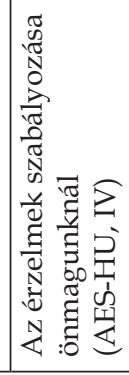 & 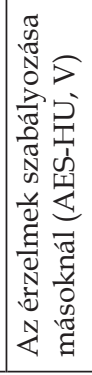 & 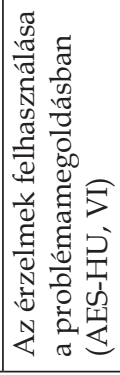 & 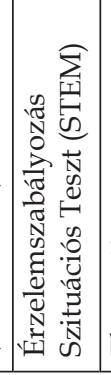 & 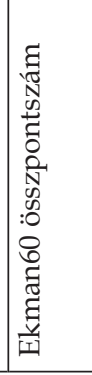 \\
\hline
\end{tabular}


A következő lépésben hierarchikus lineáris regresszió elemzéssel teszteltük, hogy a személyiségvonások mellett az érzelmi intelligencia tud-e még szignifikáns magyarázó erővel hozzájárulni az élettel való elégedettség varianciájához. A korrelációs számítások eredményei alapján itt már csak a vonás érzelmi intelligencia változót vettük figyelembe. Amikor csupán az életkort és a Big Five faktorokat léptettük be az élettel való elégedettség varianciájának magyarázatára kialakított modellünkbe (1. modell), azt találtuk, hogy ezek a változók az élettel való elégedettség szint varianciájának szignifikáns hányadát magyarázzák. A korrigált $\mathrm{R}^{2}=0,189$, ami azt jelenti, hogy ebben a magyarázómodellben az életkor és a Big Five faktorok az élettel való elégedettség varianciájának $19 \%$-át magyarázzák $(F(6,414)=17,295$; $p<0,001)$. Ha a fenti változók beléptetése után a vonás érzelmi intelligenciát is beléptetjük az élettel való elégedettség magyarázatára kialakított modellünkbe (2. modell), a megmagyarázott variancia 23,1\%-ra emelkedik (korrigált $\left.\mathrm{R}^{2}=0,231 ; F(7,413)=21,016 ; p<0,001\right)$. A 2. modell esetében az $\mathbf{R}^{2}$ változása 0,043, vagyis ha a Big Five faktorok és az életkor magyarázóerejét kontroll alatt tartjuk és így vizsgáljuk a vonás érzelmi intelligencia előrejelzó erejét az élettel való elégedettséggel kapcsolatban, ez a változó szintén szignifikáns hozzájárulást mutat $(p<0,001)$ és további $4 \%$-ot képes magyarázni az élettel való elégedettség varianciájából. Ebben a modellben azt látjuk, hogy a Big Five faktorok közül csupán az extraverzió és a neuroticizmus rendelkezik a vonás érzelmi intelligenciától megkülönböztethető, önálló magyarázóerővel az élettel való elégedettségre. Az összefüggések erőssége sorrendjében a vonás érzelmi intelligencia $(\beta=0,278 ; p<0,001)$ rendelkezik a legjelentősebb magyarázóerővel, a neuroticizmus $(\beta=-0,153 ; p=0,002)$ és az extraverzió $(\beta=0,140 ; p=0,008)$ előrejelző ereje ehhez képest mérsékeltebb. A barátságosságnak, lelkiismeretességnek és nyitottságnak pedig nincs önálló, a vonás érzelmi intelligenciától független magyarázóereje az élettel való elégedettség alakulásában (2. táblázat).

\section{Megbeszélés}

Jelen tanulmány az élettel való elégedettség vonatkozásában vizsgálta az érzelmi intelligencia szerepét, és a vonás érzelmi intelligencia mutatói mellett képesség érzelmi intelligencia komponenseket is figyelembe vett. Azt teszteltük, hogy a különbözó érzelmi intelligencia összetevők megkülönböztethető módon kapcsolódnak-e az élettel való elégedettséghez, figyelembe véve a fóbb személyiségfaktorok hatásait is, amelyek a szubjektív jóllét ismert meghatározói (Diener \& Ryan, 2009). Számos korábbi kutatás igazolta a vonás érzelmi intelligencia és a különböző boldogságmutatók közötti összefüggéseket, ugyanakkor a korábbi kutatások többsége nem vette figyelembe a Big Five faktorok esetleges befolyásoló szerepét. Továbbá, keveset tudunk a képesség érzelmi intelligencia szubjektív jóllétre gyakorolt hatásáról. 
2. táblázat. Az élettel való elégedettség magyarázó változói (a hierachikus többszörös lineáris regresszióanalízis eredményei)

\begin{tabular}{|c|c|c|c|c|}
\hline Modellek & Magyarázó változók & $\beta$ & $t$ & Korrigált $\mathbf{R}^{2}$ \\
\hline \multirow{6}{*}{ 1. modell } & Extraverzió & 0,242 & $4,901^{* *}$ & \multirow{6}{*}{0,189} \\
\hline & Barátságosság & 0,060 & 1,182 & \\
\hline & Lelkiismeretesség & 0,105 & $2,161^{*}$ & \\
\hline & Neuroticizmus & $-0,154$ & $-3,039 * *$ & \\
\hline & Nyitottság & 0,081 & 1,717 & \\
\hline & Életkor & $-0,174$ & $-3,876^{* *}$ & \\
\hline \multirow{7}{*}{ 2. modell } & Extraverzió & 0,140 & $2,664^{*}$ & \multirow{7}{*}{0,231} \\
\hline & Barátságosság & 0,004 & 0,076 & \\
\hline & Lelkiismeretesség & 0,070 & 1,454 & \\
\hline & Neuroticizmus & $-0,153$ & $-3,107^{* *}$ & \\
\hline & Nyitottság & 0,012 & 0,251 & \\
\hline & Életkor & $-0,193$ & $-4,397^{* *}$ & \\
\hline & $\begin{array}{l}\text { Vonás érzelmi intelligencia } \\
\text { (AES-HU összpontszám) }\end{array}$ & 0,278 & $4,855^{* *}$ & \\
\hline
\end{tabular}

Megjegyzés: $n=421 .{ }^{*} p<0,05 ;{ }^{* *} p<0,01$.

Ruiz-Aranda és munkatársai (2014) egészségügyi fơiskolára járó nók mintáján tesztelték a képesség érzelmi intelligencia élettel való elégedettséggel és boldogsággal mutatott összefüggéseit. Azt találták, hogy a MayerSalovey-Caruso Érzelmi Intelligencia teszt (MSCEIT, Mayer és mtsai, 2002) négy alskálája közül egyedül az érzelmek szabályozásának képességét mérő skála mutatott gyenge, pozitív irányú szignifikáns együttjárást mindkét jóllétindikátorral, a többi érzelmi intelligencia összetevő pedig függetlennek bizonyult az élettel való elégedettség és a szubjektív boldogságérzet szintjétől.

Jelen kutatás eredményei szerint mind az öt Big Five faktor szignifikáns korrelációt mutat az élettel való elégedettséggel: a neuroticizmus negatív, a többi faktor (extraverzió, barátságosság, lelkiismeretesség, nyitottság) pozitív irányban. Az extraverzióval mutatkozó közepes erósségú kapcsolat kivételével a többi összefüggés gyenge. A vonás érzelmi intelligencia összpontszáma pozitív irányú, közepes erôsségú szignifikáns kapcsolatot mutat az élettel való elégedettséggel. A vonás érzelmi intelligencia komponenseit figyelembe véve azt kaptuk, hogy az érzelmek szabályozása önmaguknál az az érzelmi intelligencia összetevő, amely a legszorosabb 
együttjárást mutatja az élettel való elégedettséggel. Ez az eredmény egybecseng Platsidou (2013) kutatásának eredményével, amely rámutatott arra, hogy azok a fiatalok, akik hatékonyak az érzelmeik szabályozásában, magasabb szinten tapasztalják meg a boldogság legtöbb komponensét, mint azok a fiatalok, akiknél ez az érzelmi intelligencia összetevő fejletlenebb. Ezek az eredmények azt sugallják, hogy az érzelmi intelligenciára, különösen a saját érzelmek szabályozásának képességére érdemes kiemelten fókuszálni azon prevenciós és intervenciós programok szervezésénél, amelyek a jóllét növelését célozzák meg.

Jelen kutatásban a hierarchikus lineáris regresszió elemzés eredménye rámutatott arra, hogy a vonás érzelmi intelligencia és az élettel való elégedettség közötti összefüggés megmarad az életkor és a személyiségváltozók (extraverzió, barátságosság, lelkiismeretesség, neuroticizmus, nyitottság) kontrollálása után is. Furnham és Petrides (2003) eredményei szerint a szubjektív boldogságérzet varianciájának több mint $50 \%$-a magyarázható a vonás érzelmi intelligenciával, és a Big Five vonások nem magyaráznak szignifikáns hányadot a boldogság varianciájából a vonás érzelmi intelligencia kiparciálása után. Jelen kutatás ehhez képest az élettel való elégedettség vonatkozásában a vonás érzelmi intelligencia lényegesen alacsonyabb, illetve a Big Five faktorok jelentősebb szerepét igazolta. Ez ez eredmény egybecseng a témában végzett későbbi kutatásokkal (Austin és mtsai, 2005; Gallagher \& Vella-Brodrick, 2008; Petrides és mtsai, 2007; Saklofske és mtsai, 2007), amelyek mérsékeltnek találták a vonás érzelmi intelligencia inkrementális validitását. Adataink azt mutatják, hogy a képesség érzelmi intelligencia nem mutat lineáris kapcsolatot sem a személyiséggel, sem az élettel való elégedettséggel. Ez az eredmény konzisztens azokkal a korábbi kutatásokkal, amelyek a képesség érzelmi intelligencia személyiségtől való függetlenségét bizonyították (pl. Nagy, 2010) és újszerú az élettel való elégedettség vonatkozásában. Ugyanakkor ez az eredmény jól magyarázható abból kiindulva, hogy az intelligenciát és a kognitív képességeket hagyományosan nem kapcsoljuk össze a jóllét területén jelentkező egyéni különbségekkel (Argyle, 2001; Eysenck, 1990). Továbbá, ez az eredmény alátámasztja Petrides és Furnham (2001) feltételezését, amely szerint a vonás érzelmi intelligencia és a képesség érzelmi intelligencia világosan megkülönböztethető, független konstruktumok.

A jelen kutatás erősségei között említhető, hogy nem kizárólagosan egyetemistákat vizsgált, és az érzelmi intelligencia mérőeszközeinek széles tárházát vonta be, továbbá, úgy vizsgálta az érzelmi intelligencia és élettel való elégedettség összefüggéseit, hogy közben az általános személyiségváltozókat statisztikailag kontrollálta, figyelembe véve, hogy a személyiség szignifikáns meghatározója a boldogságnak (pl. Diener \& Ryan, 2009; Nagy \& Gyurkovics, 2016). 
A kutatásunk korlátainak számbavételekor figyelembe kell venni, hogy az érzelmi intelligencia skálák és az élettel való elégedettség között korrelációkat számoltunk, ez pedig keveset mond nekünk azon mögöttes folyamatokról, amelyek közvetítenek a jóllét és érzelmi intelligencia között, és ezek alapján az sem világos, hogy az érzelmi intelligencia okozója vagy következménye a mentális egészségi állapotnak. Elméletileg az alacsony érzelmi intelligencia a mentális betegségek okozójaként és következményeként (szimptómájaként) egyaránt elképzelhetó (Extremera, Ruiz-Aranda, PinedaGalán, \& Salguero, 2011). További korlátként említhetjük kutatásunk keresztmetszeti elrendezését, valamint az eredmények általánosíthatóságának korlátozottságát, amely a kényelmi mintavételból adódik.

A jövőbeli kutatások során a fejlődési változások követhetősége érdekében longitudinális adatgyújtést lenne érdemes alkalmazni. További kutatásoknak kell tisztázni, hogy ha a képesség érzelmi intelligencia nem járul hozzá az élettel való elégedettség magasabb szintjéhez, akkor vajon milyen területen azonosíthatóak az elónyei. Lehetséges az is, hogy korai ezzel kapcsolatban állást foglalnunk, mivel napjainkig a képesség érzelmi intelligencia mérőeszközei még pszichometriailag nem tökéletesen kimunkáltak, ahogy azt a jelen kutatásban a teljesítményteszteknél tapasztalt, az elvártnál alacsonyabb megbízhatósági mutatók is jól jelzik. A jövő feladatai közé tartozik a teljesítményalapú érzelmi intelligencia további mérőeszközeinek kifejlesztése és a meglévők tökéletesítése is. Eredményeink természetesen nem általánosíthatók a jóllét általános kérdéskörére, mivel kutatásunkban kizárólag a szubjektív jóllét kognitív komponensét, az élettel való elégedettség szintjét vettük figyelembe. Elképzelhető, hogy az érzelmi jóllét, vagy a pszichológiai jóllét vonatkozásában eltérő eredményeket kapnánk. Ezek tesztelése is a jövőbeli kutatások kihívásai közé tartozik.

\section{Nyilatkozat érdekütközésról}

A szerző ezúton kijelenti, hogy esetében nem állnak fenn érdekütközések.

\section{Irodalom}

Andrei, F., Siegling, A.B., Aloe, A.M., Baldaro, B., \& Petrides, K.V. (2016). The incremental validity of the Trait Emotional Intelligence Questionnaire (TEIQue): A systematic review and meta-analysis. Journal of Personality Assessment, 98(3), 261-276.

Argyle, M. (2001). The psychology of happiness. London: Routledge

Austin, E.J. (2010). Measurement of ability EI: Results for two new tests. British Journal of Psychology, 101(3), 563-578.

Austin, E.J., Saklofske, D.H., \& Egan, V. (2005). Personality, well-being, and health correlates of trait emotional intelligence. Personality and Individual Differences, 38(3), 547-558. 
Bar-On, R. (1997). The Emotional Intelligence Inventory (EQ-i): Technical manual. Toronto: Multi-Health Systems

Burns, N.R., Bastian, V.A., \& Nettelbeck, T. (2007). Emotional intelligence: More than personality and cognitive ability? In G. Matthews, M. Zeidner, \& R.D. Roberst (Eds.), The science of emotional intelligence: Knowns and unknowns (167-196). New York: Oxford University Press

Chamorro-Premuzic, T., Bennett, E., \& Furnham, A. (2007). The happy personaliy: Mediational role of trait emotional intelligence. Personality and Individual Differences, 42(8), 1633-1639.

Chiarrochi, J.V., Chan, A.Y.C., \& Bajgar, J. (2001). Measuring emotional intelligence in adolescents. Personality and Individual Differences, 31(7), 1105-1119.

Day, A.L. (2004). The measurement of emotional intelligence: The good, the bad, and the ugly. In G. Geher (Ed.), Measuring emotional intelligence: Common ground and controversy (245-270). Hauppauge, NY: Nova Science

Diener, E. (1984). Subjective well-being. Psychological Bulletin, 95(3), 542-575.

Diener, E. (2000). Subjective well-being: The science of happiness and a proposal for a national index. American Psychologist, 55(1), 34-43.

Diener, E., \& Ryan, K. (2009). Subjective well-being: a general overview. South African Journal of Psychology, 39(4), 391-406.

Diener, E., Emmons, R.A., Larsen, R.J., \& Griffin, S. (1985). The Satifaction with Life Scale. Journal of Personality Assessment, 49(1), 71-75.

Ekman, P., \& Friesen, W.V. (1978). Facial action coding system: Investigators's guide. Palo Alto, California: Consulting Psychologist Press

Extremera, N., \& Fernandez-Berrocal, P. (2005). Perceived emotional intelligence and life satisfaction: Predictive and incremental validity using the Trait Meta-Mood Scale. Personality and Individual Differences, 39(5), 937-948.

Extremera, N., Ruiz-Aranda, D., Pineda-Galán, C., \& Salguero, J-M. (2011). Emotional intelligence and its relation with hedonic and eudaimonic well-being: A prospective study. Personality and Individual Differences, 51(1), 11-16.

Eysenck, M. (1990). Happiness: Facts and myths. Hove: LEA

Furnham, A., \& Petrides, K.V. (2003). Trait emotional intelligence and happiness. Social Behavior and Personality, 31(8), 815-823.

Gallagher, E.N., \& Vella-Brodick, D.A. (2008). Social support and emotional intelligence as predictors of subjective well-being. Personality and Individual Differences, 44(7), 1551-1561.

Gignac, C.E., Palmer, B.R., Manocha, R., \& Stough, C. (2005). An examination of the factor structure of the Schutte self-report emotional intelligence (SSREI) scale via confirmatory factor analysis. Personality and Individual Differences, 39(6), 1029-1042.

John, O.P., Donahue, E.M., \& Kentle, R. (1991). The „Big Five” inventory- Version $4 a$ and 54. Berkeley: University of California, Berkley, Institute of Personality and Social Research

John, O.P., \& Srivastava, S. (1999). The Big-Five trait taxonomy: History, measuremenet, and theoretical perspectives. In L.A. Pervin, \& O.P. John (Eds.), Handbook of personality: Theory and research (102-138). New York: Guilford Press

Kong, F., Zhao, J., \& You, X. (2012). Emotional intelligence and life satisfaction in Chinese university students: The mediating role of self-esteem and social support. Personality and Individual Differences, 53(8), 1039-1043.

Kun, B., Balázs, H., Kapitány M., Urbán R., \& Demetrovics, Zs. (2010). Confirmation of the three factor model of Assessing Emotions Scale (AES): Verification of the theoretical starting point. Behavioral Research Methods, 42(2), 596-606. 
Kun, B., Urbán, R., Balázs, H., Kapitány, M., Nagy, H., Oláh, A., et al. (2011). Az Érzelmek Mérése Skála háromfaktoros modelljének adaptálása. Magyar Pszichológiai Szemle, 66(3), 449-455.

Librecht, N., \& Lievens, F. (2012). Validity evidence for the situational judgment test paradigm in emotional intelligence measurement. International Journal of Psychology, $47(6), 438-447$.

MacCann, C., \& Roberts, R.D. (2008). New paradigms for assessing emotional intelligence: Theory and data. Emotion, 8(4), 540-551.

Martins, A., Ramalho, N., \& Morin, E. (2010). A comprehensive meta-analysis of the relationship between emotional intelligence and health. Personality and Individual Differences, 49(6), 554-564.

Martos, T., Sallay, V., Désfalvi, J., Szabó, T., \& Ittzés, A. (2014). Az Élettel való Elégedettség Skála magyar változatának (SWLS-H) pszichometriai jellemzői. Mentálhigiéné és Pszichoszomatika, 15(3), 289-303.

Mayer, J.D., Salovey, P., \& Caruso, D.R. (2002). Mayer-Salovey-Caruso Emotional Intelligence Test (MSCEIT): User's Manual. Toronto: Multi-Health Systems Incorporated

Nagy, H. (2010). A képesség-alapú érzelmi intelligencia modell érvényességének empirikus elemzése. Phd. disszertáció. Eötvös Loránd Tudományegyetem, Pedagógiai és Pszichológiai Kar, Pszichológiatudomány Doktori Iskola.

Nagy, H. (2012). Az Érzelmek Mérése Skála (AES-HU) faktorszerkezetének és validitásának elemzése. Magyar Pszichológiai Szemle, 67(3), 431-447.

Nagy, H., \& Gyurkovics, M. (2016). A pszichológiai jóllét szociodeográfiai korrelátumai, kapcsolata a big five vonásokkal és az optimizmussal. Mentálhigiénéés Pszichoszomatika, 17(3), 195-214.

Nagy, H., Magyaródi, T., \& Séllei, B. (2015). A képességalapú érzelmi intelligencia: Új paradigmák a tesztfejlesztésben és pontozásban, hazai tapasztalatok az érzelemmegértés és érzelemszabályozás szituációs tesztekkel. Magyar Pszichológiai Szemle, 70(4), 827-846.

Palmer, B., Donaldson, C., \& Stough, C. (2002). Emotional intelligence and life satisfaction. Personality and Individual Differences, 33(7), 1091-1100.

Petrides, K.V., \& Furnham, A. (2001). Trait emotional intelligence: Psychometric investigation with reference to established trait taxonomies. European Journal of Personality, 15(6), 425-448.

Petrides, K.V., \& Furnham, A. (2003). Trait emotional intelligence: Behavioral validation in two studies of emotion recognition and reactivity to mood instruction. European Journal of Personality, 17(1), 39-57.

Petrides, K.V., Pérez-González, J.C., \& Furnham, A. (2007). On the criterion and incremental validity of trait emotional intelligence. Cognition and Emotion, 21(1), 25-55.

Platsidou, M. (2013). Trait emotional intelligence predicts happiness, but how? An empirical study in adolescents and young adults. International Journal of Wellbeing, 3(2), 197-209.

Proctor, C., Tweed, R., \& Morris, D. (2014). The naturally emerging structure of well-being among young adults. Big Two or other framework. Journal of Happiness Studies, 16(1), 257-275.

Rode, J.C., Arthaud-Day, M.L., Mooney, C.H., Near, J.P., \& Baldwin, T.T. (2008). Ability and personality predictors of salary, perceived job success, and perceived career success in the initial career stage. International Journal of Selection and Assessment, 16(3), 292-299.

Rózsa, S., Kálmán, R., Kő, N., Nagy, H., Fiáth, T., \& Oláh, A. (2012). Az érzelmi arcfelismerés mérése és jelentősége a pszichológiai kutatásokban: Az Ekman 60 Arc Teszttel szerzett hazai tapasztalatok. Pszichológia, 32(3), 229-251.

Rózsa, S. (2010). A Big Five Inventory magyar adaptációja. Kézirat. Budapest: Eötvös Loránd Tudományegyetem 
Ruiz-Aranda D., Extremera, N., \& Pineda-Galán, C. (2014). Emotional intelligence, life satisfaction and subjective happiness in female students health professionals: the mediating effect of perceived stress. Journal of Psychiatric and Mental Health Nursing, 21(2), 106-113.

Ryan, R.M., \& Deci, E.L. (2001). On happiness and human potentials: a review of research on hedonic and eudaimonic well-being. Annual Review of Psychology, 52(1), 141-166.

Saklofske, D.H., Austin, E.J., Galloway, J., \& Davidson, K. (2007). Individual difference correlates of health-related behaviours: Preliminary evidence for links between emotional intelligence and coping. Personality and Individual Differences, 49(3), 491-502.

Saklofske, D.H., Austin, E.J., \& Minski, P. (2003). Factor structure and validity of trait emotional intelligence measure. Personality and Individual Differences, 34(4), 707-721.

Salovey, P., \& Mayer, J.D. (1990). Emotional intelligence. Imagination Cognition, and Personality, 9(3), 185-211.

Schutte, N.S., Malouff, J.M., Bobnik, C., Coston, T.D., Greeson, C., Jedlicka, C., et al. (2001). Emotional intelligence and interpersonal relations. Journal of Social Psychology, 141(4), 523-536.

Schutte, N.S., Malouff, J.M., Hall, L.E., Haggerty, D.J., Cooper, J.T., Golden, C.J., et al. (1998). Development and validation of a measure of emotional intelligence. Personality and Individual Differences, 25(2), 167-177.

Schutte, N.S., Malouff, J.M., Thorsteinsson, E.B., Bhullar, N., \& Rooke, S.E. (2007). A metaanalytic investigations of the relationship between emotional intelligence and health. Personality and Individual Differences, 42(6), 921-933.

Szondy, M. (2010). Optimizmus, pesszimizmus, egészség. Doktori disszertáció. Budapest: Eötvös Loránd Tudományegyetem

Urguigo, I., Extremera, N., \& Villa A. (2015). Emotional intelligence. Life satisfaction, and Psychological well-being in graduates: the mediating effect of perceived stress. Applied Research Quality Life, 11(4), 1241-1252.

Webb, C.A., Schwab, Z.J., Weber, M., DelDonno, S., Kipman, M., Weiner, M.R., et al. (2013). Convergent and divergent validity of integrative versus mixed model measures of emotional intelligence. Intelligence, 41(3), 149-156.

\section{Personality, emotional intelligence and life satisfaction}

\section{BÁNYAI-NAGY HENRIETT}

Background: Previous research has found small but reliable relationships between emotional intelligence and some components of well-being. The strength of these relationships varies as a function of the way of emotional intelligence is measured, and it is still unclear whether emotional intelligence can predict well-being after controlling for the Big Five factors, which are also reliable predictors of subjective well-being. Aim: This study examined the relationship between the Big Five personality traits, trait and ability-based emotional intelligence and life satisfaction. Method: In our cross-sectional study 421 persons (166 men and 255 women) took part. The participants completed the Assessing Emotions Scale, the Situational Test of Emotion Management, the Ekman 60 Faces Scale, the Big Five Inventory, and the Satisfaction with Life Scale. Results: We found that, four Big Five traits (extraversion, agreeableness, conscientiousness, openness) were positively and neuroticism was negatively correlated with both life satisfaction $(r=.20-.33, p<.01)$ and trait-emotional 
intelligence $(r=.21-.55, p<.01)$. According to the results of hierarchical regression extraversion, neuroticism and trait-emotional intelligence had an unique significant effect on life satisfaction. The trait-emotional intelligence can account for a significant additional variance in SWLS scores after controlling for the Big Five factors (adjusted $R^{2}=0.231$, $F(7,413)=21.016, p<.001)$. In contrast, the ability-EI scales were independent from both personality traits and life satisfaction. Conclusion: Our findings are consistent with previous studies confirming the Big Five factors play an important role in the life satisfaction, and demonstrated that trait-emotional intelligence is a fundamental in affecting one's subjective well-being.

Keywords: subjective well-being, life satisfaction, personality, Big Five factors, emotional intelligence 